\title{
KESIAPAN PEMBELAJARAN IPS DALAM MENGHADAPI ERA REVOLUSI INDUSTRI 4.0 MENUJU SOCIETY 5.0
}

\author{
Nurhalisa \\ Program Studi Pendidikan Ilmu Pengetahuan Sosial \\ Fakultas Keguruan dan Ilmu Pendidikan \\ Universitas Lambung Mangkurat \\ nhalisa1901@gmail.com
}

\begin{abstract}
ABSTRAK
Dewasa ini pembelajaran menghadapi tantangan baru yaitu berkembangnya Revolusi Industri 4.0. Revolusi industri 4.0, sudah mulai menetrasi berbagai aspek kehidupan, dan tatanan sosial. Dunia pendidikan nasional khususnya dalam pembelajaran, tidak memiliki pilihan selain merespon tantangan tersebut. Pembelajaran harus siap dalam menghadapi tantangan ini dimana guru harus mampu menyiapkan perangkat pembelajaran yang mampu membuat peserta didik dapat berfikir secara logis apalagi dimasa adanya pandemic Covid-19 ini, seperti melalui mobile digital dengan memanfaatkan beberapa platform online seperti classroom, grub WA, aplikasi zoom, gmeet dan lain-lain. Menekankan pada model pembelajaran daring (online), menyediakan sumber belajar yang beragam, dan mampu mengembangakan media pembelajaran inovatif sesuai dengan karakteristik pembelajaran yang diajarkan pada setiap satuan pendidikan. Beberapa sekolah menunjukkan bahwa pembelajaran yang berlangsung selama ini sudah baik dan guru sudah memanfaatkan media sebagai penunjang pembelajaran. Namun karakteristik guru yang beragam dan tuntutan perkembangan pembelajaran yang semakin maju manuntut perlunya penyesuaian.
\end{abstract}

Kata Kunci: Pembelajaran, Pendidikan, Revolusi.

\section{PENDAHULUAN}

Perkembangan teknologi informasi mempunyai pengaruh di segala kehidupan, walaupun awalnya perkembangan tersebut dirasakan di lembaga-lembaga yang bergerak di bidang ekonomi (perusahaan). Begitu juga Revolusi Industri 4.0 membawa dampak 
tidak hanya pada pendekatan baru tetapi juga metodologi dan teknologi pada perusahaan, yang dalam perkembangannya berpengaruh juga diberbagai ilmu pengetahuan. Karenanya sudah waktunya diperkenalkan kepada masyarakat, utamanya akademisi (Benesovaa \& Tupaa, 2017:2195). Menghadapi era revolusi industri 4.0, peransatuan pendidikan khusunya pada pembelajaran IPS menjadi sangat penting, terutama dalam perkembangannya ilmu pengetahuan dan teknologi. Oleh karenanya, pembelajaran IPS yang harus mendorong semakin terbukanya pengetahuan yang mampu meningkatkan kesejahteraan, toleransi serta terciptanya budaya multikulturalisme di dalam masyarakat. Di era revolusi 4.0 sekarang ini, banyaknya kasus intoleransi didalam berbagai media sosial sehingga mengakibatkan krisis keberagaman didalam masyarakat Indonesia.

Seharusnya pembelajaran yang sekarang tidak hanya terfokus pada cara melihat kemampuan kognitif peserta didik, namun bagaimana tujuan pembelajaran dari sisi kognitif, afektif dan psikomotorik dapat tercapai dengan melihat hasil pembelajaran secara konkret. Sanaky (2013:215) mengemukakan perkembangan pesat di dunia teknologi informasi khususnya internet, akan mempercepat aliran ilmu pengetahuan yang dapat menembus batas-batas dimensi ruang, birokrasi, kemampanan, dan waktu. Pembelajaran IPS sudah seharusnya dilihat secara umum dengan melihat proses terjadinya perubahan secara menyeluruh. Winkel (2009 : 104) menyatakan bahwa hasil belajar adalah perubahan yang mengakibatkan manusia berubah dalam sikap dan tingkah lakunya sehingga dapat menjadi indikator kualitas dan kuantitas peserta didik. Banyaknya persoalan yang dihadapi pembelajaran ini mencakup lemahnya penggunaan teori, miskinnya imajinasi, acuan buku teks dan kurikulum yang state oriented, serta kecenderungan untuk tidak memperhatikan fenomena globalisasi berikut latar belakang historisnya (Subakti,2010).

\section{PEMBAHASAN}

Pembelajaran IPS sebagai bekal dalam menghadapi perubahan zaman, Pembelajaran IPS bukan hanya konsep atau teori, tetapi implementasi dari pembelajaran IPS itu menjadi pedoman bagi peserta didik untuk dapat memecahkan persoalan sosial. Pembelajaran IPS harus bertransformasi menjadi pembelajaran yang menarik dan menyenangkan, kreatif, menumbuhkan rasa ingin tahu yang tinggi, berpikir kritis, 
berpendapat, kolaborasi dalam tim, kepekaan sosial, dan kemampuan pemecahan masalah. Peran pendidikan IPS tidak hanya sekedar membuat peserta didik cerdas, namun juga menjadi warga negara yang baik, berjiwa sosial, berakhlak, dan berkarakter. Oleh karena itu, dalam menghadapi tantangan di era ini diperlukan kolaborasi semua pihak meliputi sekolah, keluarga, masyarakat, serta pemerintah dalam rangka meningkatkan kualitas pendidikan di era revolusi industri 4.0. menuju society 5.0.

Revolusi industry 4.0 menempatkan Guru sebagai fasilitator yang harus memiliki kemampuan kreatif dalam membangun pengetahuan bagi mahasiswa. Proses belajar sejarah harus lebih mementingkan proses bukan sekedar hasil belajar yang tertuang dalam nilai akhir pada setiap proses pembelajaran. Tuntutan perkembangan teknologi harus secara sigap mampu ditangkap dengan baik melalui kesiapan pendidik dalam merancang pembelajaran yang kritis, keratif dan inovatif. Dengan datangnya era Revolusi Industri 4.0 memunculkan permasalah baru lagi yaitu bagaimana dengan perkembangan teknologi informasi seorang pendidik IPS mampu menggunakan teknologi dengan tepat guna dan menyampaikan materi yang berdaya guna. Dengan perkembagan teknologi informatika berbagai informasi dapat diakses oleh siapa saja melalui media sosial, semua informasi tidak mungkin ditutupi. Kondisi semacam ini seorang guru IPS sudah seharusnya meningkatkan berbagai kompetensinya. Menurut Gleason (2018) "masyarakat dunia saat ini mengalami masa transisi untuk itu perlu adanya adaptasi untuk menjalani era revolusi industri 4.0”. Melakukan adaptasi dari setiap perubahan membutuhkan kerja keras agar semua berjalan saling berdampingan dan tidak menimbulkan permasalahan dikemudian hari. Namun sayangnya perubahan teknologi bergerak lebih progresif dibandingkan dengan sumber daya manusianya.

Pembelajaran IPS hendaknya berusaha selalu berinovatif senyampang dengan perkembangan teknologi kalau tidak ingin ketinggalan zaman. Sebenarnya semua ini sangat dilematis karena tidak semua pendidik IPS mempunyai kemampuan dalam mengikuti perkembangan teknologi dan ketersediaan serta kesiapan perangkat lunak yang menyertainya di setiap sekolah. Pembelajaran IPS harus bertransformasi menjadi pengajaran yang menarik dan menyenangkan, oleh karena itu peran guru sangat penting untuk melakukan banyak perubahan mulai dari berubahnya mindset, media pembelajaran, metode mengajar, update informasi, menguasai teknologi, menguasai literasi, dsb. Pembelajaran IPS yang sering dilakukan oleh pendidik IPS yaitu seringnya 
menggunakan metode mengajar dengan ceramah, ditambah lagi dengan cara mengajar guru hanya satu arah, guru menggunakan teknik menghafal untuk mengingat pelajaran, mencatat materi, mempelajari Lembar Kerja Siswa (LKS), siswa kurang berpikir kritis, pengajaran yang hanya menekankan aspek kognitif namun aspek afektif serta psikomotorik kurang ditekankan, pengajarannya bukan mementingkan proses, dan berbagai pembelajaran IPS lainnya. Akibatnya pembelajaran yang dilaksanakan mata pelajaran IPS dianggap sebagai mata pelajaran yang jenuh dan membosankan bagi siswa. Maka berbagai pembelajaran seperti itu sudah tidak relevan lagi, seorang guru dapat menggunakan berbagai pembelajarannya dengan berbagai cara dan disesuaikan dengan kondisi siswa saat ini misalnya penerapan pengajaran student centered learning , diskusi, pengajaran yang menitik beratkan pada studi kasus dan pemecahan masalah, model pengajaran inquiry, pengajaran problem based learning, cooperative learning, role playing, dsb. Konsep-konsep pembelajaran ilmu pengetahuan sosial juga harus ikut sesuai dengan perkembangan zaman. Menurut tujuan pembelajaran Ilmu Pengetahuan Sosial, adalah membentuk dan mengembangakan seseorang menjadi warga negara yang baik. Secara umum identitas warga negara yang baik menurut Robert Barr seperti yang ditulis oleh (Ilbert et al., 2013), dapat digambarkan sebagai berikut: 1.) Mempunyai sikap patriotik (mencintai tanah air, bangsa dan negara), 2.) Menghormati dan memahami nilai, sistem, dan praktik kehidupan sosial, 3.) Memiliki integritas sosial dan tanggung jawab sebagai warga negara, 4.) Memahami dan menghormati nilai budaya atau tradisi yang diwarisi oleh negara, 5.) Memiliki motivasi untuk berpratisipasi aktif dalam penyelengaraan kehidupan demokrasi 6.) Sadar akan masalah yang terjadi di lingkungan sosial, 7.) Mempunyai sikap, ide danketerampilan sebagai warga negara, 8.) Memiliki pemahaman dan penghormatan terhadap sistem ekonomi saat ini.

Pada era revolusi industri 4.0 ini ditandai dengan masuknya budaya luar yang tidak sesuai dengan budaya bangsa masuk ke Indonesia yang tidak sesuai dengan budaya bangsa. Sehingga generasi muda banyak mengikuti budaya luar ditambah lagi pondasi dasar generasi muda sangat lemah karena mereka masih melakukan pencarian identitas diri, sehingga banyak diantara mereka yang salah bergaul dan cenderung melakukan perbuatan yang melanggar nilai dan norma di masyarakat. Pembelajaran IPS semampunya dapat menjadi pelopor untuk dapat membantu dalam menanamkan nilainilai dan norma- norma sosial di masyarakat sehingga peserta didik dapat 
mengimplementasikan nilai-nilai dan norma sosial dalam kehidupan sehari-hari misalnya nilai sosial, nilai kebaikan, nilai religius, norma kesusilaan, norma agama, norma hukum, dsb. Pengimplementasian nilai dalam kehidupan siswa menjadi pondasi dasar sebagai upaya preventif yang untuk menghindari siswa dari dampak negatif pergaulan remaja seperti seks bebas, narkoba, bullying, dsb. Karena itu pendidikan nasional harus dijalankan secara kontekstual dan fungsional, Pendidikan kita harus berakar pada aspirasi dan kebutuhan masyarakat pendukungnya yang secara sosial budaya dan lingkungan alamiahnya. Oleh karena itu Pendidikan di abad 4.0 perlu ditanamkan nilai-nilai kewarganegaraan (good citizen), kekaryaan (good worker), dan nilai kemanusiaan (good human) (Abduhzen, 2018).

Tantangan berikutnya adalah rekonstruksi kurikulum pembelajaran IPS yang responsif terhadap revolusi industri juga diperlukan, seperti desain ulang kurikulum dengan pendekatan human digital dan keahlian berbasis digital. Sistem pembelajaran berbasis teknologi informasi nantinya diharapkan menjadi solusi bagi anak bangsa di pelosok daerah untuk menjangkau pendidikan tinggi yang berkualitas. Persiapan dalam menghasilkan lulusan yang mampu beradaptasi dengan Revolusi Industri 4.0 adalah satu diantara cara yang dapat dilakukan lembaga pendidikan untuk meningkatkan daya saing terhadap kompetitor dan daya tarik bagi peserta didik. Kualitas guru dalam menghadapi era revolusi industri 4.0 harus ditingkatkan sesuai dengan kebutuhan zaman. Apalagi dengan adanya sistem belajar yang berbasis teknologi seperti elearning, ujian yang sudah berbasis komputer, penilaian dengan menggunakan e-rapor, media pembelajaran yang menggunakan proyektor, laptop, dan sebagainya. Hal ini membuat guru diharapkan untuk dapat menggunakan media tersebut dengan baik. Atas dasar itu, disinilah peran guru IPS sebagai mediator yang dapat memahami dan dapat menggunakan berbagai media pembelajaran dalam pendidikan IPS.

Dalam konstek Ilmu Sejarah, tujuan dalam memahami masa lalu adalah menjadi manusia yang bijak atau wise atau bijak dalam masa kini dan masa depan. Proses menuju individu atau masyarakat menuju wise dapat melalui pengambilan aspek nilai dan hikmah dari peristiwa yang terjadi di masa lalu (A.L. Rowse, 2014: 168). Dengan demikian, melalui sejarah dapat ditekankan proses pendidikan nilai. karakter merupakan pedoman ataupun konsepsi ideal yang mengarahkan kebiasaan dan keputusan serta membantu suatu individu atau masyarakat dalam menentukan baik atau buruknya suatu 
dala kategori monadic (baik, buruk, sangat buruk) ataupun dyadic (lebih baik, lebih buruk dan seimbang) (Hansson, 2004: 15). Keberadaan karakter dalam konstruk diri seseorang individu akan membentuk kesadaran dalam membangun perbuatan, sikap ataupun keputusan yang baik. karakter juga berperan penting dalam membangun kerangka interaksi dan kehidupan sosial yang mencakup enam kerangka tujuan yaitu: (1) nilai bagi diri sendiri; (2) orang lain; (3) lingkungan; (4) pengetahuan ;(5)m potensi; dan (6) komunitas (Koutsaukis, 2009: iv-vii).

\section{SIMPULAN}

Era Revolusi Industri 4.0 membawa dampak besar bagi pembelajaran baik terkait dengan pengguaan media, metode, berbagai model pembelajaran, substansi IPS yang tidak hanya terdapat buku-buku cetak, tetapi di media sosial. Satu sisi semua ini akan menjadi rahmat, tetapi satu sisi aka nmenjadi musibah kalau pendidik IPS tidak selektif dan selalu meningkatkan kompetensinya. Karena itu diperlukan beberapa kompetensi yang dipersiapkan era industri 4.0, selain kompetensi yang diamanatkan oleh Permendiknas No.16 Tahun 2017. Kompetensi tersebut adalah kemampuan memecahkan masalah (problem solving), beradaptasi (adaptability), kolaborasi (collaboration), kepemimpinan (leadership), dan kreatifitas serta inovasi (creativity and innovation). Apapun perubahan yang terjadi IPS tetap menjadi mata pelajaran sangat penting karena secara substansial IPS merupakan pengalaman hidup bangsa, sehingga ada pribahasa "pengalaman adalah guru yang utama". Sehingga dengan mempelajari pengalaman hidup tersebut akan menjadi orang yang bijaksana karena masa lalu sebagai cermin untuk bertindak dimasa sekarang dan masa yang akan datang.

Oleh karena itu, pendidikan Ilmu Pengetahuan Sosial yang berbasis riset harus mendorong semakin terbukanya pengetahuan yang mampu meningkatkan kesejahteraan manusia. Revolusi industri 4.0 telah mengubah paradigma masyarakat dunia hari ini. Tuntutan untuk semakin meningkatkan inovasi di segala bidang terus menguat. Pasalnya, berbagai teknologi untuk menggantikan peran manusia di bidang industri semakin bermunculan. Hal itu memunculkan tantangan agar manusia hari ini bisa terus beradaptasi dengan perubahan zaman. Memasuki era revolusi industry 4.0 yang berbasis digital, pendidikan IPS dikelola secara fleksibel tanpa terjebak rutinitas. Era tersebut mensyaratkan berbagai terobosan perguruan tinggi dalam menyiapkan sumberdaya manusia yang kompetitif. 


\section{REFERENSI}

Kochar. (2008). Pembelajaran Sejarah Teaching of History . Jakarta: PT Gramedia.

Nursyifa, A. (2019). Transformasi pendidikan ilmu pengetahuan sosial dalam menghadapi era revolusi industri 4.0. Journal of Civics and Education Studies, 6(1), 51-64.

Mariati, M., Abbas, E. W., \& Mutiani, M. (2021). The Social Science Contribution Through Social Studies Learning. The Innovation of Social Studies Journal, 2(2), 110-120.

Nugraheny, A. R. (2020). Peran teknologi, guru dan orang tua dalam pembelajaran daring di masa pandemi.

Mutiani, M. (2017). IPS dan pendidikan lingkungan: urgensi pengembangan sikap kesadaran lingkungan peserta didik. SOSIO-DIDAKTIKA: Social Science Education Journal, 4(1), 45-53.

Syaharuddin, S. (2020). Menimbang Peran Teknologi dan Guru dalam Pembelajaran di Era COVID-19. Menimbang Peran Teknologi dan Guru dalam Pembelajaran di Era COVID-19.

Abbas, E. W. (2013). Mewacanakan Pendidikan IPS. Mewacanakan Pendidikan IPS.

Syaharuddin, S., \& Mutiani, M. (2020). Strategi Pembelajaran IPS: Konsep dan Aplikasi.

Mulyadi, G. A., Firman, F., \& Rusdinal, R. (2021). Pembelajaran Ilmu Pengetahuan Sosial sebagai Sarana Pembentukan Karakter Siswa Menghadapi Revolusi Industry 4.0. Syntax Idea, 3(3), 520-532.

Putria, H., Maula, L. H., \& Uswatun, D. A. (2020). Analisis Proses Pembelajaran dalam Jaringan (DARING) Masa Pandemi Covid-19 Pada Guru Sekolah Dasar. Jurnal Basicedu, 4(4), 861-870. 